\title{
The Impact of Destination Image on Tourist Behavior: Karbala as a Case Study
}

\author{
Zuhier Abbas Azeez \\ College of Tourism Sciences, Al-Mustansiriyah University, Baghdad 10052, Iraq
}

Corresponding Author Email: zuhier.abbas1976@uomustansiriyah.edu.iq

https://doi.org/10.18280/ijsdp.160709

Received: 30 August 2021

Accepted: 10 October 2021

\section{Keywords:}

destination image, commercial brands, Karbala, consumer behavior, destination personality

\begin{abstract}
The destination image is regarded as one of the elements affecting visitors' choices in selecting tourist locations that satisfy their wants and aspirations in a way that corresponds to their expectations of such places. The destination image influences tourist behavior by stimulating tourist desires to travel and engage in tourist activities, as well as influencing that behavior in the travel decision-making process during the pre-trip, trip, and post-trip phases. The destination image is also linked to visitor satisfaction with regard to their appraisal of their travel experience and the extent to which that experience meets or comes near to their earlier expectations. Therefore, the current study looks at the image and personality of religious, tourist, and commercial brands, as well as how they connect to future tourist behavior. The study considered Karbala city, Iraq, as a case study. The study was based on the in-filed study technique, which was represented by a questionnaire that was delivered to the study sample, which consisted of seven first-class hotels in Karbala city, with 40 copies of the questionnaire handed over to the administrative personnel at these hotels. The study discovered that the cognitive image, emotional image, and destination personality all had different effects on global image and behavioral intentions for first-time and recurrent visitors. Additionally, the findings show that the qualitative remarks focused heavily on attractions, culture, and the environment. The practical consequences are explored, and destination personality and behavioral outcomes for first-time and recurrent visitors were designed and evaluated independently.
\end{abstract}

\section{INTRODUCTION}

Tourist destination images, components, and how they relate to behavioral intentions have all been the subject of many studies. For the purpose of attracting first-time tourists as well as boosting the probability of returning and recommending the location, the studies claimed that a good destination image aids. Earlier studies investigated how various industries and disciplines have applied image and personality concepts in the setting of tourism [1]. A few studies were interested in studying the overall destination image, as well as how various elements form and influence one another; while others focused on measuring how various destination images are different, depending on the reasons why they are being visited; and yet others are concerned with how various individual visitor perceptions are influenced by demographics, different reasons for visiting, and familiarity with the destination (e.g., [2, 3]). Though studies on destination image and personality have been done on many themes, fewer studies have examined the connection between the two and how they influence certain visitor populations' behavioral intentions [4].

The phrase "travel behavior" or "tourist behavior" refers to consumer behavior and is one of the most popular and relevant topics of study in tourism [5]. Travel behavior, on the other hand, is a collection of ongoing processes comprised of numerous stages and interconnected ideas that cannot always be examined individually. Consumer behavior and its understanding are among the topics that scholars and tourism professionals are interested in Ref. [6]. In this regard, there are a number of important things that affect the tourism sector, including the ability to understand the behavior of individuals around whom everything revolves, how the tourist consumer thinks and the resulting reading, and thus how tourism is affected [7]. The influence of visitor behaviour on the social, economic, and environmental systems is critical for a tourist destination and occurs at all phases of tourist travel, from planning through package selection and execution. Tourists choose separate parts of a tour package trip, such as an itinerary, or an itinerary to reach certain travel locations, while organizing a tour [8].

Previous studies sought to assess the suitability of the site to the image of the destination on tourism behaviour by stimulating the desires of tourists to travel and engage in tourism activities. This study looks at the impact of religious, tourist, and commercial brands on the image and personality of a destination. The study considered Karbala, Iraq, as a case study to examine how these factors affect tourism behaviour in the country where the brand is located.

\section{DESTINATION IMAGE}

\subsection{Defines}

Since the 1970s, the image has been a contentious issue in 
tourism literature [9]. It is generally accepted that the definition of a tourist destination is the actual area where a visitor stays for at least one night, according to Bosnić et al. [10]. An important part of the destination image is the thoughts, attitudes, and perceptions of tourists about a location [11]. They are also known as "cumulative associations and feelings throughout time"[12]. According to Kotler, the destination picture is an amalgamation of the person's feelings about the area, their perceptions, and their thoughts about it [13].

Destination pictures are described as mental representations created from a few impressions selected from travel advertising counsel, books, movies, or the media, which contain the accumulation of trip memories [14]. This is a mental image that acts as a symbol of the place, helping travelers form a first impression of it before they go there. In the evoked set, an extra piece of information is shown, along with the destination's picture, and the pictures of other possible locations are contrasted [15].

\subsection{The importance of the destination's image}

The relevance of the tourism destination image stems from the fact that it influences visitor behaviour in a variety of ways. First and foremost, it impacts the choice of a vacation place. It is true that most would-be visitors have little understanding of tourist sites they have not previously visited. Thus, the destination image is important since it performs the important role of providing stronger, good, and identifiable pictures of certain locations that are more likely to be picked up by tourists.

The study's second implication is that it influences their post-decision behaviours, such as how satisfied tourists are and whether or not they will return in the future. People return from vacation with opinions about the characteristics of a tourist location that suit their needs and expectations [16]. This means that, in addition to affecting the outcome of selection procedures, the persuasive power of the destination image may also affect the various phases of tourist consumer behaviour. Tourist behaviour before, during, and after visits is assessed by utilizing information about where tourists go to and from [17].

Several studies have found that a favourably regarded destination image is highly related to the choice of that particular location [18]. A good destination image is an advantage for any country or area that participates in the tourist business, according to [19]. It is reasonable to argue that locations with favourable pictures are more likely to succeed than those with negative reputations when competing for foreign tourists. The research highlights the importance of having a favourable image. At the same time, destination image influences two major aspects of tourist behaviour: it affects destination choice during the decision-making process, as well as after-decision-making behaviours such as participation (on-site experience), assessment (satisfaction and future behavioural intentions) (intention to revisit) [20].

The attractiveness of travel destinations varies depending on many variables, such as price, available time, season, and reputation [21]. Among the numerous sources of information that visitors utilize while formulating pre-visit destination image ideas, information gained from these sources is widely viewed as having a probable effect on the construction of the final destination image. In order to obtain information, the user's location must be known in order to establish a meaningful hypothesis. In other words, both the travel agency and the Internet are essential and oft-employed tourism information sources, which makes it all the more important to establish their role in destination image formation. This hypothesis will revolve around a picture to display for the user depending on the source or sources used [22].

Even if a person has never visited a location or sought information about it, he or she will have some sort of information stored in memory, even if it is incomplete, to which she or he will add new portions, according to Gunn. A positive or negative image can linger long after the circumstances that formed it have altered. It's also well known that photographs exhibit a high degree of consistency over time [23].

\subsection{Types of emitted images}

Universal images, ephemeral images, and induced images were discovered as three separate forms of conveyed destination visuals [24]. Starting with the premise that universal images are those that have developed and have been accepted by society, another reason why the media, literature, art, music, and other forms of reality reinterpretation produce transient images is that the media is made up of ephemeral images. Despite the fact that most individuals do not recall these sights, they can occasionally become universal images. Furthermore, because tourism promoters (such as DMOs, hotels, and tourist attractions) and travel agencies have a financial interest in building a site's image in order to market it and influence travellers' decision-making processes, these locations will end up producing induced images.

\subsection{Elements of destination images}

According to some authors, there are three major parts of the destination image that are distinct yet hierarchically interconnected as components [25-28]: cognitive, emotional, and conative components are all present.

(1) The cognitive aspect of an image describes people's beliefs and facts about a location. It usually results from examining the people who live there and the activities that take place there [29]. Thus, the cognitive aspect comprises beliefs and knowledge about the physical features of the location [30] and it is related to the beliefs and knowledge that someone has about a goal [31].

(2) The emotional component expresses how individuals feel about a location. It is more concerned with the picture of a place than with enjoying or disliking it [32], whereas the emotional component relates to sentiments and emotions linked with the place's more abstract features. The affective component relates to someone's feelings about a location [33], whereas the emotional component refers to tourists' sentiments toward that item [34].

(3) The conative element, which is the image's action component, such as the intention to return or revisit a location or to promote it [35] and it relates to behavioral intentions toward a destination [36].

\subsection{Steps of destination image construction}

Gunn [37] has identified many phases in the process of tourist image creation. These are their names:

(1) The organic picture is the collection of mental goal images. 
(2) The alteration of the original picture following information acquisition-the inciting image.

(3) The choice to travel to the destination.

(4) The visit to the destination.

(5) Disseminating the destination.

(6) The journey back to the house.

(7) The image is modified based on the experience obtained.

\subsection{Destination image dimensions}

Echtner and Ritchie [38] noted that after conceptualizing the image of tourist locations, they came to the conclusion that it might be conceived of as having both an attribute-based and a holistic component. Furthermore, although some pictures of locations are based on easily observable or quantifiable qualities (e.g., landscapes, attractions), others are based on more abstract, intangible traits (e.g., friendliness, safety). Echtner and Ritchie [39] defined destination image as "not just assessments of particular destination features but also the overall impression of the destination." The destination picture's functional elements correspond to the location's more concrete components, while psychological attributes link to the location's more ethereal aspects. As illustrated in Figure 1, the destination picture is split into two primary dimensions: attribute-based image and holistic image, both of which comprise functional and psychological aspects.

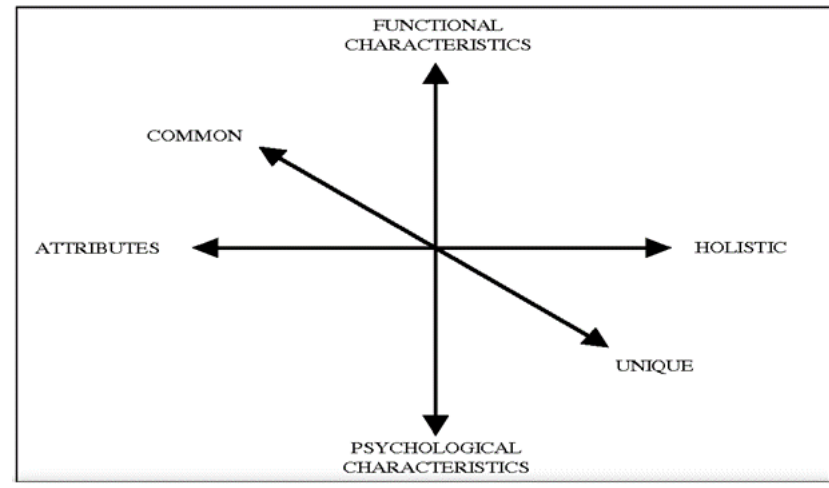

Figure 1. The destination image's dimensions [39]

\section{SECTION BEHAVIOR OF TOURISTS}

\subsection{Definitions}

The notion of "consumer behavior" refers to the actions that customers take when looking for, purchasing, using, assessing, and disposing of items and services that meet their requirements [40]. Consumer behavior may alternatively be described as any actions taken at the individual or group level that are directly related to the acquisition and use of products and services to meet current and future consumer demands, including decision-making processes that precede and decide these actions [41]. Tourist behavior in the context of consumer behavior in the acquisition, use, and abandonment of tourist services [42]. Tourist behavior may be explained in two ways, according to Pearce: emic and etic methods. The etic method, in which the researcher, as an observer and outsider, classifies and describes the tourist's conduct, is the opposite of the emic approach, in which the researcher, as an observer and outsider, classifies and characterizes the tourist's behavior [43]
Consumer behavior refers to the actions that customers take when looking for, assessing, and disposing of items and services that meet their requirements. Consumer behavior is concerned with how individuals decide how to spend their available resources (time, money, and effort) on consumptionrelated products [44].

\subsection{Influence of factors on tourist behavior}

There are three forms of tourist behavior: collectively orientation-driven travel behaviors, risk-tendency-driven travel behaviors, and social interaction-driven travel behaviors, one for each stage of a trip: before, during, and after travel [45]. Different studies have discovered elements influencing tourist travel behavior, such as characteristics driving the tourist to travel, the tourist's attitude, and various situational and environmental aspects impacting the visitor's personal significance [46]. Actually, the behavior of tourists in terms of destination selection has been studied and shown to be impacted by a variety of variables, which can be broadly divided into three groups [47].

(1) Factors affecting decision-making: Studies show that age, gender, marital status, income, education, employment, residence city, family size, automobile ownership, and lifestyle have a significant impact on tourist destination selection [48].

(2) Alternative-specific variables: These elements consist of the various qualities of destinations (such as attractiveness and tourist resources) and the ease of access (such as being readily available for travel) [48].

(3) Situational factors: These include weather conditions: climate has been implicated in several studies as a factor influencing tourist behavior [49].

This study investigates tourist behaviour: motivation, travel decision-making, and satisfaction, all of which influence the tourism image of a destination and how this destination is chosen. Tourism motivation describes the progression of tourism decisions toward the complete tourism goal. There are several such motives, which will be discussed more below. Travel decision-making describes the process of selecting a travel decision from a large number of options before, during, and after a trip.

\subsection{Motivating tourists}

Travel motives can be regarded as having significant psychological effects on tourist behavior. It is so true, since motives are generally an individual's inner moods, combined with their own wants and aspirations [50]. As a result, the travel drive has been identified as the main reason behind comprehending tourist behavior. Travel motivation has been used by researchers all over the world to predict leisure participation levels and identify travel patterns [51], as well as understand tourists' travel decisions and consumption behavior [52]. The intents and behaviors of visitors are impacted by more than one motive. In fact, visitors are motivated to travel to different destinations for a variety of reasons [53].

\subsubsection{Motivating factors in tourism}

According to Solomon and Panda [54], a variety of variables encourage customers to purchase tourist items. There are two types of motivating forces in tourism: 
a) Those that encourage, a person to take a vacation (primary demand).

b) Those that encourage, a person to take a specific vacation to a specified location at a given time (selective demand).

There is no commonly accepted method for categorizing the primary driving elements in tourism [55]. However, some of the most important are as follows:

- Physical: rest, exercise, and good health.

- Emotional: reminiscence, adventure, imagination, romance.

- Personal: visiting friends and family, the desire to please others, and economic motivations (i.e. the search for business).

- Self-development motivations: such as expanding one's knowledge or acquiring a new skill.

- Social status: exclusivity, the capacity to seek out new styles, and the ability to secure good prices.

- Cultural: learning about new cultures.

\subsection{Making travel decisions}

Travel decision-making may be summarized as "travel decision-making is a sequential and dependent process, and travellers follow a funnel-like method of limiting options among possibilities" [56]. The nature of decision making and choosing behaviour, which includes attitudes, beliefs, risk perception, characteristics, and personality, is addressed in the first of two elements of travel decision making. The second is concerned with the creation of techniques aimed at anticipating the decision-making and choice behaviour process [57]. It may be said that making a travel choice is a sequential process that begins when visitors have a desire or need to travel, is followed by an information search, an assessment of that information, and ultimately making a travel decision. So, everything the would-be tourist reads, hears, or sees would inspire him or her to define and choose their tourism option [58].

Their primary contribution was to recognize that the consumption process continues after the purchase, when tourists plan their vacation, when they experience the tourism product, and when they return home and assess their travel experience. According to Dimanche and Andrades [59], the process of making travel decisions on an individual level is impacted by a variety of elements, but may be broadly classified into two categories: Internal personal factors and external environmental ones. The researchers go on to say that, on a personal level, people's travel decisions are generally affected by their "recreational requirements." On the other hand, external factors that usually influence the travel decision process include information related to a specific destination, such as the history and culture of a country, the language, social security, and some paperwork-related information, such as that pertinent to obtaining a visa for that country, not to mention what tourism resources say about that spot and its accessibility [60].

\subsubsection{Stages of travel decision making}

Regardless of the numerous identifications of travel phases that many studies have made so far, what they all have in common is that the trip decision-making process always involves three stages: pre-, during-, and post-travel, as shown in Figure 2 [61].

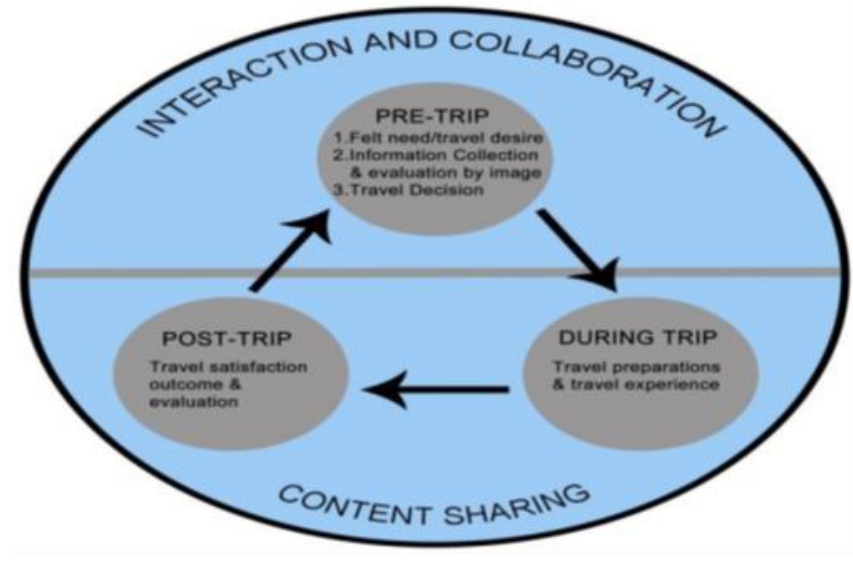

Figure 2. Tourism decision making [62]

i. The Pre-Trip

This pre-trip stage that is related to travel decisions involves getting the information necessary for these decisions to be made. The importance of this stage lies in the fact that the would-be tourist or traveller before starting his or her trip starts looking up information about places they have never been before and hence have no physical experience whatsoever. That means that the search should logically involve comparisons of products and services through the relevant information shared by family members, relatives, friends and colleagues [63].

\section{ii. The During-Trip}

It is through this stage that travellers usually experience the trip along with associated activities like the consumption of tourism products like transportation, food, accommodation, and site-seeing [64]. Furthermore, it is a stage during which tourists also start looking for more data concerning additional attractions and means of transportation available in a given location or region [65].

The importance of that lies in the fact that the would-be tourist or traveller, before starting his or her trip, starts looking up information about places they have never been before and hence have no physical experience whatsoever. That means that the search should logically involve comparisons of products and services through the relevant information shared by family members, relatives, friends and colleagues [66].

\section{iii. The Post-Trip}

The post-travel stage is the stage where satisfaction with the travel experience is assessed. During this stage, tourists tended to tell others about their experiences through the publication of their thoughts and opinions concerning a particular place or service that they received, thus, becoming a prescriber who shares feedback that could benefit future tourists [67]. This post-travel phase or stage is also referred to as the consumption experience stage, where products and services have been practically tried and evaluated so that consumers start sharing their personal experiences that could be positive or negative [68].

\subsection{Tourists satisfaction}

Since the late 1970s, a substantial body of literature in tourism and hospitality management has concentrated on customer happiness. Over the years, satisfaction has been studied from various perspectives and for various purposes 
[69], and it (i.e. satisfaction in tourism) should be studied as a system process, in which the various stages of the trip (pre-trip services, services at the destination, and transit route services) are collectively analysed [44]. One of the most well-known definitions of satisfaction refers to the degree to which pleasant sentiments are activated by an event [28]. It should also be noted that several techniques for evaluating customer satisfaction have been presented, debated, and modified thus far, and they may be broadly categorized into two primary approaches:

The first is based on the difference between expectations and perceived performance, which aids in assessing satisfaction and is one of the most commonly investigated factors of visitor satisfaction [69]. The second method includes evaluating a vacation location using the total of attribute evaluations, and researchers can only assess "the attributes of the impacts of destination image, perceived value, and service quality on visitor satisfaction and related word-of-mouth [70]. This sort of satisfaction measurement might be interpreted as an evaluation of the quality of the destination's performance, such as how visitors are handled and served, as well as how they feel about the destination [32].

\section{THE FIELD INVESTIGATION}

\subsection{Convergent validity test outcomes}

As shown in Figure 3, the results of the internal consistency test using the Cronbach Alpha coefficient, which is used to test the stability of the measuring instrument in terms of internal consistency, show that all dimensions of destination image, tourist behaviour, and questionnaire paragraphs were greater than the acceptable minimum of (0.7). The total value of Alpha Kronbach for the questionnaire paragraphs was (0.957) and a validity coefficient of $(0.978)$, confirming the consistency between the scale components and therefore the needed stability if the test is repeated.

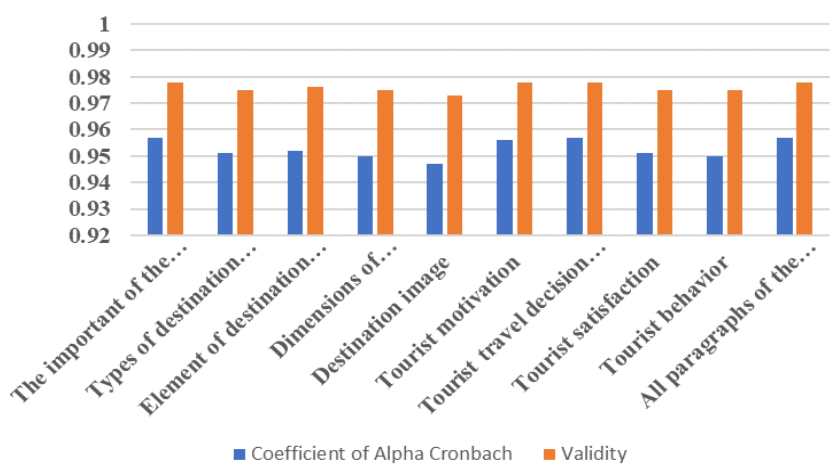

Figure 3. Internal consistency test results for variables and dimensions

\subsection{The questionnaire's reliability}

The current study used the split-half method to determine if questions were consistently marked. This entails determining if the odd and even questions match. The Spearman-Brown equation corrects the coefficient of correlation, which is accomplished with certain equations that contain the students' responses. The coefficient of correlation for the questionnaire, despite its numerous scales, was determined to be (0.872), demonstrating that the questionnaire is valid for usage at different times for the same people and yields consistent results as shown in Table 1 and Figure 4.

Table 1. Method of splitting in half

\begin{tabular}{|c|c|c|c|}
\hline \multirow{4}{*}{ Cronbach's Alpha } & Part 1 & $\begin{array}{c}\text { Value } \\
\mathrm{N} \text { of Items }\end{array}$ & $\begin{array}{c}0.934 \\
20^{\mathrm{a}}\end{array}$ \\
\hline & \multirow{2}{*}{ Part 2} & Value & 0.947 \\
\hline & & $\mathrm{N}$ of Items & $20^{\mathrm{b}}$ \\
\hline & \multicolumn{2}{|c|}{ Total $\mathrm{N}$ of Items } & 40 \\
\hline \multicolumn{3}{|c|}{ Correlation Between Forms } & 0.774 \\
\hline \multirow{2}{*}{ Spearman-Brown Coefficient } & \multirow{2}{*}{\multicolumn{2}{|c|}{$\begin{array}{l}\text { Equal Length } \\
\text { Unequal Length }\end{array}$}} & 0.872 \\
\hline & & & 0.872 \\
\hline \multicolumn{3}{|c|}{ Guttman Split-Half Coefficient } & 0.871 \\
\hline
\end{tabular}

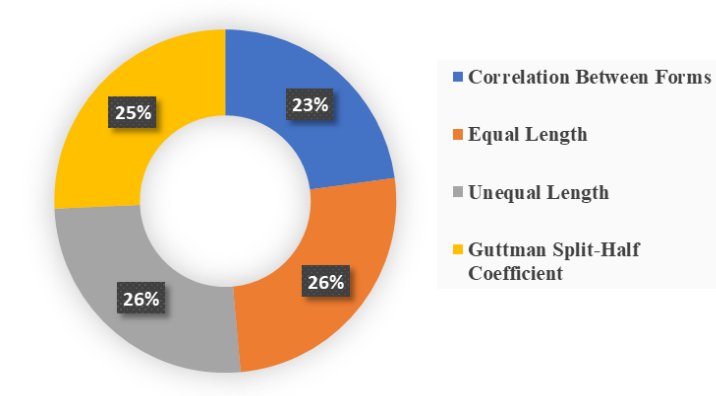

Figure 4. The questionnaire's reliability

\subsection{Reliability of confirmatory construct}

The main objective of construct reliability is to ensure that the dimensions and the items composing them fit the theoretical structure they've been built upon, by comparing the sample data to the theoretical structure described in the literature. This form of factorial analysis is an application of structural equation modeling (which is accomplished with AMOS 23), and it is also used to check for both convergent and discriminant validity. Additionally, the confirmatory construct might be validated by a number of goodness of fit criteria, such as $\mathrm{X} 2$, which is the ratio between $\mathrm{X} 2$ and the Degree of Freedom DF and which was previously applied in the current study and should not exceed X5.The study comprises two variables: tourist behavior, which comprises three dimensions (Tourist behavior: The study comprises two variables: tourist behavior, which comprises three dimensions (Tourist behavior: the characteristics and profiles of tourists (including how they act, how they make travel decisions, and how they behave in various situations), as well as a destination image, which is comprised of four dimensions (the significance of the image, various types of image, elements of image, and dimensions of image).

4.3.1 The confirmatory factorial analysis of the destination image variable

The confirmatory factorial analysis for the destination image variable according to the Modification Indices is shown in Figure 5. As indicated in the figure, all of the paragraphs of the variable - which has four major dimensions - were more than $(0.40)$ and are identical to the goodness of fit, providing a favorable signal for undertaking all additional statistical analyses, as stated in Table 2. 
Table 2. Regression weights, standard error, critical values, and degree of significance of the dimensions of the destination image variable

\begin{tabular}{|c|c|c|c|c|c|c|c|c|}
\hline Signification & $\begin{array}{c}\text { Signification level } \\
\text { at P } 0.05\end{array}$ & $\begin{array}{c}\text { Critical } \\
\text { Ration CR }\end{array}$ & $\begin{array}{l}\text { Standard } \\
\text { Error SE }\end{array}$ & $\begin{array}{c}\text { Regression } \\
\text { weights }\end{array}$ & $\begin{array}{c}\text { Standard } \\
\text { Regression weights }\end{array}$ & Dimensions & \multicolumn{2}{|c|}{ PathParagraphs } \\
\hline Significant & & & & 1.000 & .638 & \multirow{7}{*}{$\begin{array}{c}\text { The important of the } \\
\text { destination image }\end{array}$} & $--->$ & $\mathrm{X} 1$ \\
\hline Significant & $* * *$ & 4.877 & .396 & 1.933 & .984 & & $--->$ & $\mathrm{X} 2$ \\
\hline Significant & $* * *$ & 3.894 & .315 & 1.227 & .637 & & $--->$ & $\mathrm{X} 3$ \\
\hline Significant & $* * *$ & 3.457 & .354 & 1.222 & .625 & & $--->$ & $\mathrm{X} 4$ \\
\hline Significant & $* * *$ & 3.346 & .259 & .866 & .533 & & $--->$ & $\mathrm{X} 5$ \\
\hline Significant & $* * *$ & 3.628 & .332 & 1.206 & .682 & & $--->$ & X6 \\
\hline Significant & $* * *$ & 4.385 & .312 & 1.367 & .843 & & $--->$ & $\mathrm{X} 7$ \\
\hline Significant & & & & 1.000 & .499 & \multirow{5}{*}{$\begin{array}{c}\text { Types of destination } \\
\text { image }\end{array}$} & $--->$ & S8 \\
\hline Significant & .043 & 2.023 & .329 & .665 & .366 & & $--->$ & S10 \\
\hline Significant & .003 & 2.999 & .475 & 1.425 & .661 & & $--->$ & S11 \\
\hline Significant & .001 & 3.283 & .601 & 1.975 & .797 & & $--->$ & S12 \\
\hline Significant & .001 & 3.209 & .457 & 1.468 & .757 & & $--->$ & S13 \\
\hline Significant & & & & 1.000 & .709 & \multirow{5}{*}{$\begin{array}{c}\text { Element of destination } \\
\text { image }\end{array}$} & $--->$ & D14 \\
\hline Significant & $* * *$ & 3.732 & .253 & .943 & .610 & & $--->$ & D15 \\
\hline Significant & $* * *$ & 4.493 & .324 & 1.457 & .735 & & $--->$ & D16 \\
\hline Significant & $* * *$ & 3.583 & .257 & .921 & .586 & & $--->$ & D17 \\
\hline Significant & $* * *$ & 5.473 & .324 & 1.773 & .896 & & $--->$ & D18 \\
\hline Significant & & & & 1.000 & .609 & \multirow{5}{*}{$\begin{array}{c}\text { Dimensions of } \\
\text { destination image }\end{array}$} & $--->$ & H19 \\
\hline Significant & $* * *$ & 4.090 & .255 & 1.042 & .819 & & $--->$ & $\mathrm{H} 20$ \\
\hline Significant & $* * *$ & 4.469 & .395 & 1.764 & .933 & & $--->$ & $\mathrm{H} 21$ \\
\hline Significant & $* * *$ & 4.148 & .338 & 1.401 & .816 & & $--->$ & $\mathrm{H} 22$ \\
\hline Significant & $* * *$ & 4.581 & .196 & .898 & .642 & & $--->$ & $\mathrm{H} 23$ \\
\hline
\end{tabular}

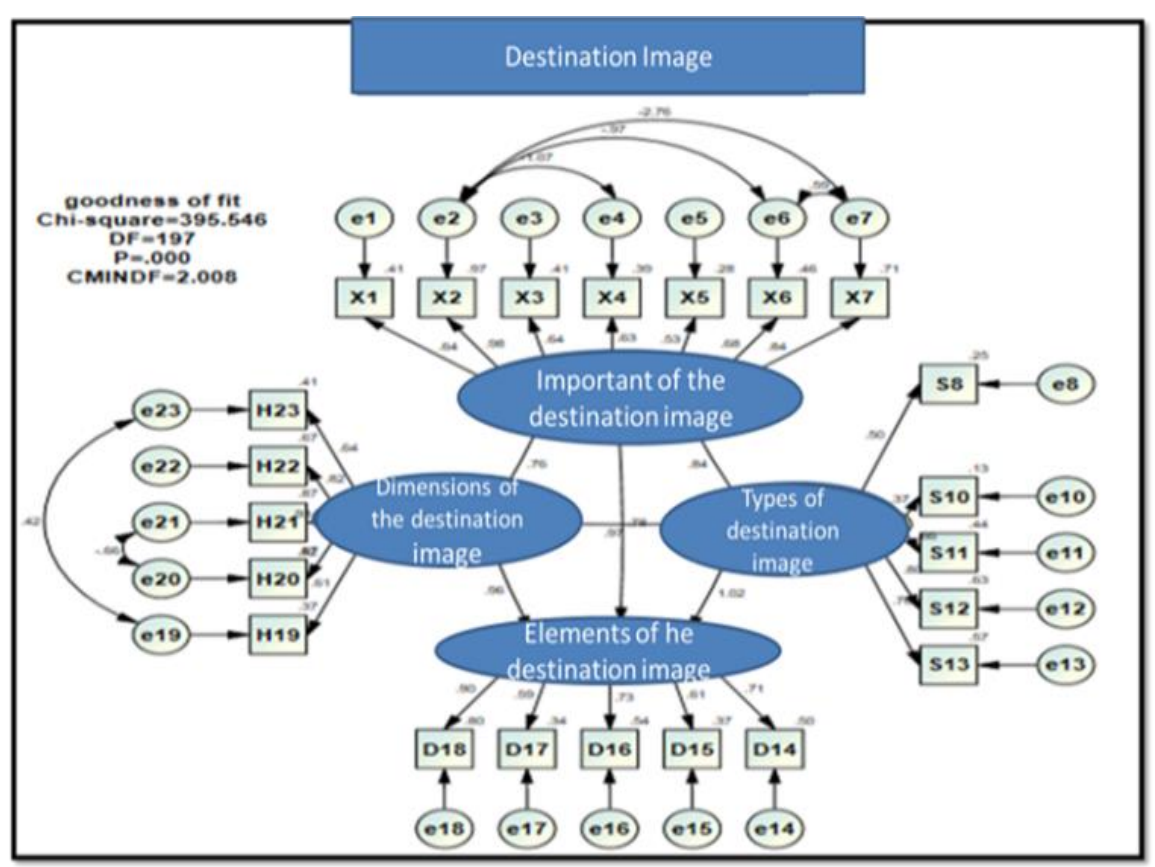

Figure 5. The target destination image variable's whole model

4.3.2 The tourist behavior variable confirmatory factorial analysis

Figure 6 depicts the confirmatory proven to enhance the tourist behaviour variable, which is made up of three major dimensions with all paragraphs according to the modification indices. The image depicts how the majority of the paragraphs of the tourist behaviour variable are larger than (0.40) and identical to the Goodness of Fit, which provides a solid signal for doing all additional statistical studies, as indicated in Table 3 .

4.3.3 Presenting the influence of destination image on tourist behavior based on the response of the sample

To learn about the reality of destination image and tourist behaviour in relation to the response of the investigated sample, a variety of metrics and tools would be utilized, including the arithmetic median, standard deviation, and weighted average, as well as the order of significance and the orientation of the sample's answer. In relation to the questionnaire responses, the five-level Likert scale was employed, so the level of each variable would be between (1-5) at four levels, as indicated in Table 4, which includes two levels in the case of an increase to the hypothetical average of (2.60-3.39). As a result, it would be ideal if it was in the (3.40-4.19) range, and even better if it was larger than that (4.20-5). It also has two levels if it falls below the hypothetical average of (2.60-3.39). Thus, it is weak if it falls within the (1.080-2.59) range and extremely weak if it falls below this level (1-1.79). 
Table 3. The regression weights, standard error, critical values, and degree of significance for the tourist behavior variable dimensions

\begin{tabular}{|c|c|c|c|c|c|c|c|c|}
\hline Signification & $\begin{array}{l}\text { Signification } \\
\text { level at } P 0.05\end{array}$ & $\begin{array}{c}\text { Critical } \\
\text { Ration } \\
\text { CR } \\
\end{array}$ & $\begin{array}{l}\text { Standard } \\
\text { Error SE }\end{array}$ & $\begin{array}{l}\text { Regression } \\
\text { weights }\end{array}$ & $\begin{array}{c}\text { Standard } \\
\text { Regression } \\
\text { weights } \\
\end{array}$ & Dimensions & Path & Paragraphs \\
\hline Significant & & & & 1.000 & .458 & \multirow{6}{*}{$\begin{array}{c}\text { Tourist } \\
\text { motivation }\end{array}$} & $--->$ & Y24 \\
\hline Significant & .021 & 2.310 & .498 & 1.150 & .500 & & $--->$ & Y25 \\
\hline Significant & .004 & 2.892 & .796 & 2.303 & .790 & & $--->$ & Y26 \\
\hline Significant & .003 & 3.019 & .908 & 2.741 & .901 & & $--->$ & Y27 \\
\hline Significant & .003 & 2.933 & .906 & 2.657 & .822 & & $--->$ & Y28 \\
\hline Significant & .002 & 3.035 & .841 & 2.553 & .917 & & $--->$ & Y29 \\
\hline Significant & & & & 1.000 & .676 & \multirow{6}{*}{$\begin{array}{c}\text { Tourist travel } \\
\text { decision - } \\
\text { making }\end{array}$} & $--->$ & P30 \\
\hline Significant & .002 & 3.144 & .206 & .647 & .531 & & $--->$ & P31 \\
\hline Significant & $* * *$ & 3.612 & .199 & .717 & .615 & & $--->$ & P32 \\
\hline Significant & $* * *$ & 3.960 & .279 & 1.105 & .808 & & $--->$ & P33 \\
\hline Significant & $* * *$ & 4.782 & .251 & 1.198 & .839 & & $--->$ & P34 \\
\hline Significant & $* * *$ & 5.304 & .275 & 1.457 & .954 & & $--->$ & P35 \\
\hline Significant & & & & 1.000 & .610 & \multirow{5}{*}{$\begin{array}{c}\text { Tourist } \\
\text { satisfaction }\end{array}$} & $--->$ & K36 \\
\hline Significant & $* * *$ & 4.106 & .430 & 1.765 & .832 & & $--->$ & K37 \\
\hline Significant & $* * *$ & 4.215 & .433 & 1.825 & .862 & & $--->$ & K38 \\
\hline Significant & $* * *$ & 3.999 & .417 & 1.666 & .797 & & $--->$ & K39 \\
\hline Significant & $* * *$ & 4.017 & .541 & 2.175 & .806 & & $--->$ & K40 \\
\hline
\end{tabular}

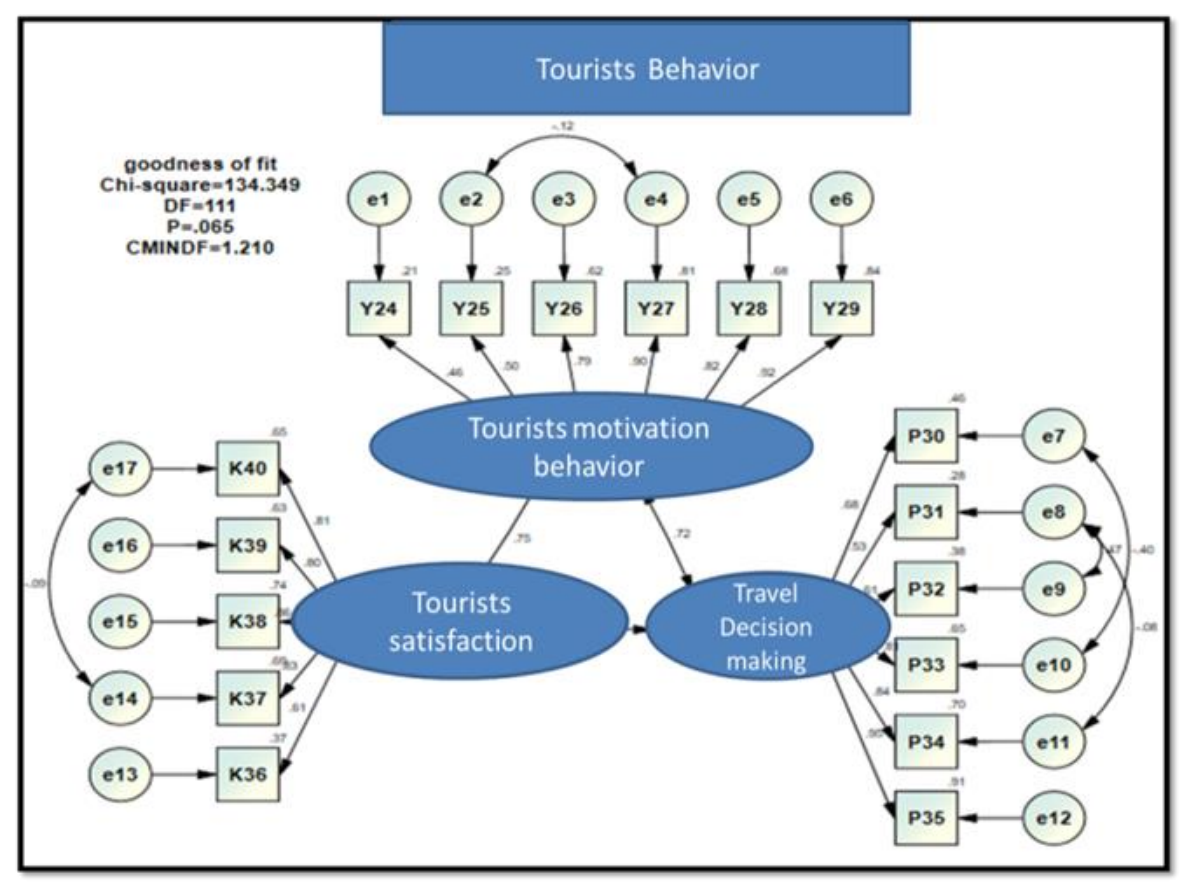

Figure 6. The complete model of tourist behavior variable

Table 4. Displays the weighted average as well as the response direction

\begin{tabular}{ccc}
\hline Weighted Average & Scale of Response & Level of Response \\
\hline From 1 to 1.79 & I totally disagree & Very weak \\
From 1.80 to 2.59 & I do not agree & Weak \\
From 2.6 to 3.39 & Neutral & Average \\
From 3.40 to 4.19 & I agree & Good \\
From 4.20 to 5 & I totally agree & Very Good \\
\hline
\end{tabular}

\section{A. Destination image}

The greatest general arithmetic median was connected to the types of destination picture dimension at (3.470), which is greater than the hypothetical median range of (2.60-3.39) at a satisfactory level since its standard deviation was (0.850) and the coefficient of variance was (0.850). (24.507). The lowest general arithmetic median had target picture dimensions of
(3.305), an average and standard deviation of (0.947), and a coefficient of variance of (28.647). Overall, the destination image variable had an arithmetic median of 3.371, a level near to satisfactory, and a standard deviation of $0 .(0.763)$.

\section{B. Tourist behavior}

The greatest general arithmetic median was associated with the "tourist motivation" dimension at (3.446), which is greater 
than the hypothetical median ranging (2.60-3.39) at a satisfactory level since its standard deviation was (0.791) and its coefficient of variance was (22.960).Tourist satisfaction had the lowest general arithmetic median at (3.350), with an average and standard deviation of (0.750) and a coefficient of variance of (22.386), since the dimension was at the second level in terms of relative significance, as indicated in the Table 5. In general, the tourist behavior variable had an arithmetic median of (3.410), a respectable level, and a standard deviation of (0.688).

\section{PUTTING THE RESEARCH HYPOTHESES TO THE TEST}

\subsection{Correlation hypothesis}

Table 6 displays the Pearson Correlation values between the variable "destination image" and its dimensions (the importance of the destination image, the types of destination image, the elements of the destination image, and the dimensions of the destination image) and the variable "tourist behavior."

I. Using a coefficient of 6t, test the research's first major hypothesis, which states that there is a significant relationship between destination image and visitor behavior. Table 6 demonstrates relationships between the aspects of a destination's image and visitor behavior. Dimensions of the destination picture Correlation Value and Significance Level Attitudes of tourists. The significance of the destination image Correlation $0.574 * *$ Signification 0.000 Destination Image Correlation 0.743** Signification 0.000 Dimensions of destination image Correlation $0.720 * *$ Signification 0.000 Destination Image Correlation $0.737 * *$ Signification 0.000 Correlation is significant at the 0.01 (2-tailed) level. The correlation is significant at the 0.05 level (2-taile at a significance level of (0.000), indicating the existence of a meaningful relationship at the "good" level, implying that destination image plays an effective and vital role in attaining visitor behavior.

II. Testing the first sub-hypothesis of the research, which states (there is a significant relationship between the importance of the destination image and tourist behavior) as the coefficient of correlation between the importance of the destination image and tourist behavior came at $(* * 0.574)$ at the level of significance of (0.000), indicating the existence of a significant relationship at a good level (there is a relationship of significance between types of the destination image.

Table 5. The arithmetic mean, standard deviation, coefficient of variance, and relative significance of the search variables

\begin{tabular}{ccccc}
\hline Dimensions of the Variables of Research & Arithmetic Mean & Standard Deviation & Coefficient of Variance & Relative Importance \\
\hline The important of the destination image & 3.368 & 0.844 & 25.046 & 3 \\
Types of destination image & 3.470 & 0.699 & 20.916 & 1 \\
Element of destination image & 3.342 & 0.947 & 28.647 & 4 \\
Dimensions of destination image & 3,305 & 0.850 & 24.507 & 2 \\
Destination Image & 3.371 & 0.763 & 22.642 & 2 \\
Tourist motivation & 3.446 & 0.791 & 22.960 & 3 \\
Tourist travel decision - making & 3.435 & 0.750 & 22.386 & 2 \\
Tourist satisfaction & 3.350 & 0.734 & 21.378 & 1 \\
Tourist Behavior & 3.410 & 0.688 & 20.168 & 1 \\
\hline
\end{tabular}

Table 6. Relationship between the aspects of a destination's image and visitor behavior

\begin{tabular}{ccc}
\hline Destination image dimensions & Value of Correlation and Level of Signification & Tourist behavior \\
\hline \multirow{2}{*}{ The important of the destination image } & Correlation & $0.574^{* *}$ \\
& Signification & 0.000 \\
Types of destination image & Correlation & $0.743^{* *}$ \\
& Signification & 0.000 \\
Element of destination image & Correlation & $0.667^{* *}$ \\
& Signification & 0.000 \\
Dimensions of destination image & Correlation & $0.720^{* *}$ \\
& Signification & 0.000 \\
Destination Image & Correlation & $0.737^{* *}$ \\
& Signification $~$ & 0.000 \\
& $* *$ Correlation is significant at the 0.01 level (2-tailed) & \\
& $*$ Correlation is significant at the 0.05 level (2-taile) & \\
\hline
\end{tabular}

Table 7. Statistical indicators evaluating the relationship between destination image dimensions and tourist behavior

\begin{tabular}{ccccccc}
\hline Dimensions of destination image & Constant A & Marginal Regression B & F Test & R2 & Sig & Signification \\
\hline The important of the destination image & & 0.468 & 18.655 & 0.329 & 0.000 & Significant \\
Types of destination image & 1.835 & 0.708 & 40.851 & 0.518 & 0.000 & Significant \\
Element of destination image & 1.043 & 0.485 & 30.512 & 0.445 & 0.000 & Significant \\
Dimensions of destination image & 1.808 & 0.601 & 46.865 & 0.552 & 0.000 & Significant \\
Destination image & 1.325 & 0.664 & 45.244 & 0.544 & 0.000 & Significant \\
\hline
\end{tabular}




\subsection{Influence hypotheses}

This section focuses on the influence of hypotheses discovered in the study, with the goal of accepting or rejecting them. Thus, the hypothesis (there is a significant relationship between the dimensions of the destination image and tourist behaviour) will be tested. Where (a) is a constant related to tourist behaviour, and $(\mathrm{Y})$ is a function of the real value of the dimensions of the destination image, represented by (The importance of the destination image, types of destination image, elements of the destination image, and dimensions of the destination image). As Table 7 illustrates the statistical indices between the destination image dimensions and tourist behaviour, the levels of impact between the variables should be investigated.

a) Testing the second main hypothesis of the research, which states that (there is a significant relationship between destination image and tourist behaviour), the (F) value calculated between destination image and tourist behaviour was (45.244), which is greater than (4.08) at a significance level of (0.000), which is less than the level of significance at (0.05), implying the existence of a relationship. In other words, the various types of destination image have a clear and effective influence (impact) on tourist behaviour, as evidenced by the value of the coefficient of marginal regression of (0.664), with a one-unit rise in destination image leading to a one-unit increase in tourist behaviour (66\%). The coefficient of determination (R2) was (0.544), indicating that the destination image variable could explain (54\%) of the tourist behaviour variable, as shown in Table 7 .

b) Testing the first sub-hypothesis of the research, which states (there is a significant relationship between the importance of the destination image and tourist behavior), as the (F) value calculated between the importance of the destination image and tourist behavior was (18.655), which is greater than (4.08) at a level of significance of (0.000), which is less than the level of significance at $(0.05)$. That is, there is a significant influence (impact) between the importance of the destination image and tourist behavior, i.e. the importance of the destination image has a strong clear influence on enhancing tourist behavior. The value of the coefficient of marginal regression (0.468) indicates that increasing the dimension of the importance of the destination image by one unit would result in an increase in tourist behavior of (46\%), as the coefficient of determination (R2) was (0.329), indicating that the dimension "The importance of the destination image" can explain (32\%) of the tourist behavior (8).

c) Testing the second sub-hypothesis of the research, which states that (there is an influence of significance between the Types of destination image and tourist behavior), as the calculated (F) value between the dimension of "Types of destination image and tourist behavior" was (40.851), which is greater than (4.08) at the level of significance of $(0.000)$, which is less than the level of significance at (40.851). (0.05). This indicates the existence of a significant influence between the Types of destination image and tourist behavior, as it is clear from the value of the coefficient of marginal regression of (0.708) that an increase in the Types of destination image by one unit would lead to a (70 percent) increase in tourist behavior, since the coefficient of determination (R2) was (0.518), implying that (8).

\section{CONCLUSIONS}

The destination image consists of different cognitive, emotional, and influential elements, all being hierarchically interrelated, revealing the tourist's idea about tourist attractions. The study examined how these factors affect tourism behaviour in the country where the brand is located. Presented study conclusions can be drawn as follows:

(1) The destination image depends on physical dimensions, like images of tourist attraction centers and landscape images, as well as non-physical dimensions like the friendliness and safety prevailing in these places, all adding a positive value to the destination image generated in the tourist's mind.

(2) Tourist behavior is characterized by the inclination to purchase tourist services and products, where the tourist spends time, money, and labor consuming these products.

(3) Factors impacting tourist behavior vary, including gender, age, and social status, in addition to alternative factors like the characteristics of tourist destinations as well as factors of environmental nature, like the climate.

(4) The results showed the acceptance of the main correlation hypothesis, which stipulates the existence of a relationship of significance between destination image and tourist behaviour, as the coefficient of correlation factor was (0.737), which is indicative of a good relationship of significance. Also, it shows that the destination image has an essential and effective role in tourist behaviour.

(5) The results of the field study showed that the highest value of correlation in regards to the sub-hypotheses was related to the hypothesis suggesting a relationship between the types of destination image and tourist behaviour, as it reached (0.743), which means the existence of the highest correlation of good significance. It also means that the types of destination image have an essential and effective role in tourist behaviour.

(6) The results of the field study showed the acceptance of the main hypothesis of influence, stating that there is an influence of significance between the dimensions of the destination image on tourist behavior, with the calculated (F) value being (45.244), which indicates the existence of an influence of significance between destination image and tourists.

(7) The results of the field study showed that the highest value of influence in regards to the sub-hypotheses was related to the hypothesis suggesting an influence of significant between the dimensions of the destination image on tourist behavior, as the calculated (F) value was (46.865), which indicates the existence of an influence of significance, meaning the influence of the dimensions of the destination image on tourist behavior.

\section{REFERENCES}

[1] Kavoura, A. (2014). A conceptual communication model for nation branding in the Greek Framework. Implications for Strategic Advertising Policy. Procedia- 
Social and Behavioral Sciences, 148: 32-39. https://doi.org/10.1016/j.sbspro.2014.07.015

[2] Chetthamrongchai, P. (2017). The influence of travel motivation, information sources and tourism crisis on tourists' destination image. Journal of Tourism and Hospitality, 6(2). https://doi.org/10.4172/21670269.1000278

[3] Hui, T.K., Wan, T.W.D. (2003). Singapore's image as a tourist destination. International Journal of Tourism Research, 5(4): 305-313. https://doi.org/10.1002/jtr.437

[4] Jenkins, O.H. (1999). Understanding and measuring tourist destination images. International Journal of Tourism Research, 1(1): 1-15. https://doi.org/10.1002/(SICI)15221970(199901/02)1:1<1::AID-JTR143>3.0.CO;2-L

[5] Cohen, S.A., Prayag, G., Moital, M. (2014). Consumer behaviour in tourism: Concepts, influences and opportunities. Current issues in Tourism, 17(10): 872909. https://doi.org/10.1080/13683500.2013.850064

[6] Mill, R.C., Morrison, A.M. (2002). The Tourism System. Kendall Hunt.

[7] Kasapi, I., Koc, M. (2012). Changing tourism consumer behavior: The impacts on tourism demand in Albania. Creative and Knowledge Society, 2(2): 16-34. https://doi.org/10.2478/v10212-011-0023-3

[8] Strugar, M.J., Boljević, A., Boljević, S. (2017). Environmentally sustainable tourist behaviour in the function of sustainable development. EXPRES 2017: 83 .

[9] Stepchenkova, S., Mills, J.E. (2010). Destination image: A meta-analysis of 2000-2007 research. Journal of Hospitality Marketing \& Management, 19(6): 575-609. https://doi.org/10.1080/19368623.2010.493071

[10] Bosnić, I., Tubić, D., Stanišić, J. (2014). Role of destination management in strengthening the competitiveness of Croatian tourism. Ekonomski vjesnik: Review of Contemporary Entrepreneurship, Business, and Economic Issues, 27(1): 153-170.

[11] Molina, A., Gómez, M., Martín-Consuegra, D. (2010). Tourism marketing information and destination image management. African Journal of Business Management, 4(5): 722-728. https://doi.org/10.5897/AJBM.9000651

[12] Kim, H., Richardson, S.L. (2003). Motion picture impacts on destination images. Annals of Tourism Research, 30(1): 216-237. https://doi.org/10.1016/S0160-7383(02)00062-2

[13] Gallarza, M.G., Saura, I.G., García, H.C. (2002). Destination image: Towards a conceptual framework. Annals of Tourism Research, 29(1): 56-78. https://doi.org/10.1016/S0160-7383(01)00031-7

[14] Garay Tamajón, L., Cànoves Valiente, G. (2017). Barcelona seen through the eyes of TripAdvisor: Actors, typologies and components of destination image in social media platforms. Current Issues in Tourism, 20(1): 3337. https://doi.org/10.1080/13683500.2015.1073229

[15] Bilim, Y., Bilim, M.B. (2014). Does a destination have personality? Personality and image issues of a destination. Athens Journal of Tourism, 1(2): 121-134.

[16] Pavlovic, D.K., Belullo, A. (2011). Internet-an agent of tourism destination image formation: Content and correspondence analysis of Istria travel related websites. Ekonomska Istrazivanja, 24(1): 541-555.

[17] Melo, H.M.P., Moniz, A.I.A., Silva, F. (2016). Tourist destination image and consumer behaviour: The case of the Azores. CEEAplA-A-Working Paper Series, 1-9.
[18] Chen, C.F., Tsai, D. (2007). How destination image and evaluative factors affect behavioral intentions? Tourism Management, $\quad$ 28(4): $1115-1122$. https://doi.org/10.1016/j.tourman.2006.07.007

[19] Sönmez, S., Sirakaya, E. (2002). A distorted destination image? The case of Turkey. Journal of Travel Research, 41(2):

185-196. https://doi.org/10.1177/004728702237418

[20] Kanwel, S., Lingqiang, Z., Asif, M., Hwang, J., Hussain, A., Jameel, A. (2019). The influence of destination image on tourist loyalty and intention to visit: Testing a multiple mediation approach. Sustainability, 11(22): 6401. https://doi.org/10.3390/su11226401

[21] Bornhorst, T., Ritchie, J.B., Sheehan, L. (2010). Determinants of tourism success for DMOs \& destinations: An empirical examination of stakeholders' perspectives. Tourism Management, 31(5): 572-589. https://doi.org/10.1016/j.tourman.2009.06.008

[22] Frías, D.M., Rodríguez, M.A., Alberto Castañeda, J., Sabiote, C.M., Buhalis, D. (2012). The formation of a tourist destination's image via information sources: The moderating effect of culture. International Journal of Tourism Research, 14(5): 437-450. https://doi.org/10.1002/jtr.870

[23] Fakeye, P.C., Crompton, J.L. (1991). Image differences between prospective, first-time, and repeat visitors to the Lower Rio Grande Valley. Journal of Travel Research, 30(2):

$10-16$. https://doi.org/10.1177/004728759103000202

[24] Camprubí, R., Guia, J., Comas, J. (2009). Managing induced tourism image: Relational patterns and the life cycle. Tourism: An International Interdisciplinary Journal, 57(3): 241-258.

[25] Revilla Hernández, M., Santana Talavera, A., Parra López, E. (2016). Effects of co-creation in a tourism destination brand image through twitter. Journal of Tourism, Heritage \& Services Marketing (JTHSM), 2(1): 3-10. https://doi.org/10.5281/zenodo.376341

[26] Baloglu, S., McCleary, K.W. (1999). A model of destination image formation. Annals of Tourism Research, 26(4): 868-897. https://doi.org/10.1016/S0160-7383(99)00030-4

[27] Baloglu, S., McCleary, K.W. (1999). US international pleasure travelers' images of four Mediterranean destinations: A comparison of visitors and nonvisitors. Journal of Travel Research, 38(2): 144-152. https://doi.org/10.1177/004728759903800207

[28] Coban, S. (2012). The effects of the image of destination on tourist satisfaction and loyalty: The case of Cappadocia. European Journal of Social Sciences, 29(2): 222-232.

[29] İlban, M.O., Köroğlu, A., Bozok, D. (2008). Termal turizm amaçlı seyahat eden turistlerde destinasyon imaj1: Gönen örneği.

[30] Hosany, S., Ekinci, Y., Uysal, M. (2006). Destination image and destination personality: An application of branding theories to tourism places. Journal of Business Research, 59(5): 638-642. https://doi.org/10.1016/j.jbusres.2006.01.001

[31] Gartner, W.C. (1994). Image formation process. Journal of Travel \& Tourism Marketing, 2(2-3): 191-216. https://doi.org/10.1300/j073v02n02_12

[32] Prayag, G. (2008). Image, satisfaction and loyalty-The case of Cape Town. Anatolia, 19(2): 205-224. 
https://doi.org/10.1080/13032917.2008.9687069

[33] Pike, S., Ryan, C. (2004). Destination positioning analysis through a comparison of cognitive, affective, and conative perceptions. Journal of Travel Research, 42(4): 333-342. https://doi.org/10.1177/0047287504263029

[34] Li, J.J., Ali, F., Kim, W.G. (2015). Reexamination of the role of destination image in tourism: An updated literature review. E-Review of Tourism Research, 12.

[35] Khuong, M.N., Phuong, N.T. (2017). The effects of destination image, perceived value, and service quality on tourist satisfaction and word-of-mouth-A study in Ho Chi Minh City, Vietnam. International Journal of Trade, Economics and Finance, 8(5): 217-224.

[36] Feldmane, Z. (2015). Projected and perceived image of Latvia as a tourist destination (Doctoral dissertation).

[37] Gunn, C. A. (1988). Vacationscape: Designing tourist regions. Van Nostrand Reinhold.

[38] Echtner, C.M., Ritchie, J.B. (1993). The measurement of destination image: An empirical assessment. Journal of Travel Research, 31(4): 3-13. https://doi.org/10.1177/004728759303100402

[39] Echtner, C.M., Ritchie, J.B. (2003). The meaning and measurement of destination image:[Reprint of original article published in v. 2, no. 2, 1991: 2-12.]. Journal of Tourism Studies, $\quad$ 14(1): https://doi.org/10.3316/ielapa.200305723

[40] Hawkins, D., Best, R.J., Coney, K.A. (2009). Consumer Behavior. McGraw-Hill Publishing.

[41] Dumitrescu, L., Fuciu, M. (2015). Consumer behaviour in the tourist segmentation process-A marketing research. Studies in Business and Economics, 10(1): 66-76.

[42] Juvan, E., Omerzel, D.G., Maravić, M.U. (2017). Tourist behaviour: An overview of models to date. In Management International Conference, pp. 24-27.

[43] Pearce, P.L. (2005). Tourist Behaviour: Themes and Conceptual Schemes. Channel View Publications.

[44] Guleria, S. (2016). Understanding the importance of study of tourist behaviour and its relevance in growth of tourism: A study of elements influencing tourist behaviour. Amity Research Journal of Tourism, Aviation and Hospitality, 1(2): 17-24.

[45] Bodosca, Ş., Gheorghe, G., Nistoreanu, P. (2014). Tourist consumption behaviour before and after the crisis from 2008. Procedia Economics and Finance, 16: 77-87. https://doi.org/10.1016/S2212-5671(14)00777-1

[46] Wu, L. (2012). A tourist behavior model system with multi-faceted dependencies and interactions. Doctoral dissertation, Hiroshima University.

[47] Nicolau, J.L., Mas, F.J. (2005). Stochastic modeling: A three-stage tourist choice process. Annals of Tourism Research, 32(1): 49-69. https://doi.org/10.1016/j.annals.2004.04.007

[48] Awaritefe, O. (2004). Motivation and other considerations in tourist destination choice: A case study of Nigeria. Tourism Geographies, 6(3): 303-330. https://doi.org/10.1080/1461668042000249638

[49] Eugenio-Martin, J.L., Campos-Soria, J.A. (2010). Climate in the region of origin and destination choice in outbound tourism demand. Tourism Management, 31(6): 744-753. https://doi.org/10.1016/j.tourman.2009.07.015

[50] Van Vuuren, C., Slabbert, E. (2012). Travel motivations and behaviour of tourists to a South African resort. Tourism \& Management Studies, 295-304.
[51] Preko, A., Doe, F., Dadzie, S.A. (2019). The future of youth tourism in Ghana: motives, satisfaction and behavioural intentions. Journal of Tourism Futures. https://doi.org/10.1108/JTF-12-2016-0059

[52] Chang, L., Stylos, N., Yeh, S., Tung, Y. (2015). How do motivation, pre-visit information search and destination image affect post-visit behavioural intention? The case of an island destination. European Journal of Tourism Research, 9(1): 8-23.

[53] Funk, D.C., Bruun, T.J. (2007). The role of sociopsychological and culture-education motives in marketing international sport tourism: A cross-cultural perspective. Tourism Management, 28(3): 806-819. https://doi.org/10.1016/j.tourman.2006.05.011

[54] Solomon, M.R., Panda, T.K. (2004). Consumer behavior, buying, having, and being. Pearson Education India.

[55] Swarbrooke, J., Horner, S. (2007). Consumer behaviour in tourism. Routledge.

[56] Choi, S., Mattila, A.S., Van Hoof, H.B., Quadri-Felitti, D. (2017). The role of power and incentives in inducing fake reviews in the tourism industry. Journal of Travel Research, 56(8): 975-987. https://doi.org/10.1177/0047287516677168

[57] Dunne, G., Flanagan, S., Buckley, J. (2011). Towards a decision making model for city break travel. International Journal of Culture, Tourism and Hospitality Research. https://doi.org/10.1108/17506181111139573

[58] Al-Aayib, A.A., Azeez, Z.A. (2020). The effect of tourism communication on the marketing of tourism services: A field study in the marshes of southern Iraq. International Journal of Psychosocial Rehabilitation, 24(8).

[59] Dimanche, F., Andrades, L. (Eds.). (2015). Tourism in Russia: A management handbook. Emerald Group Publishing.

[60] Lin, L., Ou, S., Chen, S. (2011). Introduction of leisure and recreation.

[61] Song, H., Sparks, B.A., Wang, Y. (2017). Exploring disagreement prevention and resolution in travel decision-making of young Chinese travelers. Journal of Travel \& Tourism Marketing, 34(2): 257-273. https://doi.org/10.1080/10548408.2016.1156615

[62] Dwityas, N.A., Briandana, R. (2017). Social media in travel decision making process. International Journal of Humanities and Social Science, 7(7): 291-292.

[63] Matikiti-Manyevere, R., Kruger, M. (2019). The role of social media sites in trip planning and destination decision-making processes. African Journal of Hospitality, Tourism and Leisure, 8(5): 1-10.

[64] Azeez, Z. (2020). The effect of tourism media on the sustainable tourism: Applicable study in Iraqi board of tourism. International Journal of Psychosocial Rehabilitation, 24(8): 3894-3908.

[65] Van der Bank, C.M., van der Bank, M. (2014). The impact of social media: advantages or disadvantages. African Journal of Hospitality, Tourism and Leisure, 4(2): 1-9.

[66] Guerreiro, C., Viegas, M., Guerreiro, M. (2019). Social networks and digital influencers: Their role in customer decision journey in tourism. Journal of Spatial and Organizational Dynamics, 7(3): 240-260.

[67] Disegna, M., Osti, L. (2016). Tourists' expenditure behaviour: The influence of satisfaction and the dependence of spending categories. Tourism Economics, 
22(1): 5-30. https://doi.org/10.5367/te.2014.0410

[68] Neal, J.D., Gursoy, D. (2008). A multifaceted analysis of tourism satisfaction. Journal of Travel Research, 47(1): 53-62. https://doi.org/10.1177/0047287507312434

[69] Bradley, G.L., Sparks, B.A. (2012). Antecedents and consequences of consumer value: A longitudinal study of timeshare owners. Journal of Travel Research, 51(2):
191-204. https://doi.org/10.1177/0047287510396099

[70] Khuong, M.N., Phuong, N.T. (2017). The effects of destination image, perceived value, and service quality on tourist satisfaction and word-of-mouth-A study in Ho Chi Minh City, Vietnam. International Journal of Trade, Economics and Finance, 8(5): 217-224. 